\title{
GENETIC PARAMETERS FOR GROWTH PERFORMANCE TRAITS OF EGYPTIAN BARKI LAMBS USING RANDOM REGRESSION MODEL
}

\author{
Melak, Sh. ${ }^{1}$, Mansour H. ${ }^{2}$, Aboul-Naga A.M. ${ }^{1}$, Mona A. Osman ${ }^{1}$, \\ Elbeltagy A.R. ${ }^{1}$ and Manal El Sayed ${ }^{2}$
}

1. Animal Production Research Institute (APRI), Agriculture Research Center (ARC), Ministry of Agriculture and Land Reclamation, Dokki, Giza, Egypt

2. Animal Production Dept., Fac. of Agric., Ain Shams Univ., P.O. Box 68, Hadyek Shoubra 11241 Cairo, Egypt

*Corresponding author: melakshaa@yahoo.com

\begin{abstract}
Variance components and genetic parameters for growth traits were estimated for Barki lambs using the average information REMLF90 (AIREMLF90). A total of 3205 Barki lambs' records over the period from 1984 to 2017 from experimental Borg Al-Arab station belonging to Animal Production Research Institute (APRI) were analyzed by fitting Random Regression Model (RRM) with Legendre polynomials (LPs) for body weight traits from birth up to 480 days. Gender, type of birth, year, season and age of dam were considered as fixed effects in addition to the fixed regression on Legendre polynomials, while random regression of additive genetic and permanent environmental effects were considered as random factors in the model. The results showed that all fixed factors and some interactions were significant for all studied traits $(P<0.05)$. Quadratic equation was the best description for growth curve. Additive genetic and permanent environment variances ranged from 0.88 to 6.08 and from 0.88 to 15.33 for birth and thirteen months weights, respectively. Additive genetic and permanent environment covariances ranged from 0.05 to 16.06 and from 0.08 to 9.20 for birth with six months weights and for weaning with ten months weights, respectively. Direct and total heritabilities ranged from 0.05 to 0.41 and from 0.08 to 0.74 for four months and birth weights, respectively. Additive, genetic and phenotypic correlation coefficients were the lowest between birth weight with other studied traits and
\end{abstract}

the highest between ten months weight with other studied traits. Phenotypic variances were oscillated between 2.27 for birth weight to 22.56 for seven months weight, while, residual variances were oscillated between 0.06 for birth weight to 14.05 for four months weight. Therefore, ten months of age recommended to be the best criterion for selecting Egyptian Barki lambs for meat production.

Keywords: Barki sheep, growth performance, genetic and non-genetic factors, Random regression model.

\section{INTRODUCTION}

Lamb's growth performance is an important economic trait in sheep production. The first step to design effective breeding strategies for genetic improvement is estimating the genetic parameters (Gowane et al 2015) taking into account the relative importance of additive genetic and permanent environment for growth in this breeding strategy (Talebi et al 2007). Egyptian sheep are widely distributed in rural areas and considered as an important source of income for smallholder. More than five million heads from three main indigenous sheep breeds are raised in Egypt (FAOSTAT, 2016). Barki sheep is one of the most important types of sheep that originated in the Libyan city of Burka and were raised along the northern coast (Fahmy et al 1969) with population size of half million heads (Salwa El-Wakil et al 2008). It is one of fat-tailed sheep breeds with low growth potential 
compared with other indigenous breeds and is mostly adapted to the arid range conditions (Fahmy et al 1969). However, most of the studies on Barki sheep have so far concentrated on evaluating the breed based on phenotypic parameters. Few studies estimated the genetic merits for economically traits under certain assumptions that were made to facilitate the analysis. Most of them ignored the (co)variance structure of the traits when analyzed simultaneously considering the genetic and non-genetic factors under more realistic assumptions.

With the beginning of the $21^{\text {st }}$ century, random regression model (RRM), as one of the covariance functions, became a common methodology for estimating genetic parameters from longitudinal data (Schaeffer, 2004). The first investigation of covariance function was in 1990 for mice growth (Kirkpatrick et al 1990), but now there are many articles which investigated the possibility of applying RRM in a wide variety of time-dependent traits (Fischer et al 2004, Oliveira et al 2010 and Zamani et al 2016). In Egyptian sheep and goats, Mekkawy (2000) and Mousa et al (2006) used RRM with second order of Legendre polynomials for Zaraibi goats and Farafra sheep' genetic studies, respectively. Most models such as repeatability model assumes the homogeneity of variance and this gave genetic correlation equal to unity between repeated measures (Mansour et al 1981). Multivariate analysis takes into account the heterogenetic variances and covariances in repeated measurements but its mathematical is difficult and its computation needs long time, in addition to estimate large number of parameters (Mekkawy, 2000). All these models assume the covariance structure is discontinuous (Van der Werf and Schaeffer, 1997). Meyer (1998) used covariance function as a continuous function and Schaeffer and Jamrozik (2008) suggested random regression model as an alternative methodology to estimate the (co)variance of longitudinal data or records with repeated measurement.

The use of measurements whatever the variability of the ages at taken the weights, reduced number of estimated parameters compared with multivariate analysis and lower estimate for stander error compared with univariate analysis are additional features of the random regression model (Fischer et al 2004). Furthermore, The RRM can take into account the environmental effects of the measurement time and can also accommodate genetic differences in the shape of each animal's growth curve (Schaeffer, 2004 and Meyer, 2004).
Legendre polynomials are suitable, flexible and don't rely on predefined structures when describe the change of covariance over time in addition to their ease of calculation (Kirkpatrick et al 1990). This study aimed to: 1) Investigate the effect of non-genetic factors on all body weight traits. 2) Estimate (co)variance components such as additive genetic, permanent environment, phenotypic and residual variances. 3) Estimate genetic parameters using random regression model with second order Legendre polynomials by AIREMLF90.

\section{MATERIALS AND METHODS}

\section{Data description}

Data comprised 60895 weight records related to 1563 Barki males and 1642 females progeny of 142 sires and 968 dams. The data collected at monthly intervals up to 480 days over the period from 1984 through 2017 from experimental Borg Al-Arab station belonging to APRI were utilized to estimate (co)variance components and genetic parameters for all body weights. Also, the effects of gender, type of birth, season, year and age of dam at lambing on all body weight traits were studied. The most important economic traits were Bwt=birth weight, Wwt=weaning weight (60 days), 6wt= weight at 180 days, $10 \mathrm{wt}=$ weight at 300 days, $12 \mathrm{wt}=$ weight at yearling and $16 \mathrm{wt}=$ weight at 480 days.

\section{Management}

An accelerated lambing system of a crop every eight months was practiced. Mating seasons were January, May and September and therefore, lambs were dropped in June, October and February. Only weight not less than $35 \mathrm{~kg}$ was permitted for ewe to join the first time to enter the mating. Ewes were randomly divided into mating groups of 20 to 25 ewes. Each group was exposed to a fertile ram, about 540 days of age, in a separate mating pen for a period of 35 to 45 days. Ram should be replaced by another, in case of failing to mate the ewes after one week. Lambs were kept with their dams in nursery facility all the time up to weaning at eight weeks of age. Lambs were weighed monthly until 540 days of age.

In the morning, lambs were fed ad libitum on wheat straw or rice stubbles, which available, in addition to a concentrate mixture consisting of (24\% yellow corn, 38\% cotton-seed meal, 34\% wheat bran, $3 \%$ Molasses and $1 \%$ salt). During 

random regression model

November to May the lambs were allowed to graze Egyptian clover pasture (Trifolium alexandrinum). In the rest of the year, they graze crop stubbles and green fodder, if available, while clover hay or silage may be offered. Extra supplement of concentrate feed of $250 \mathrm{~g}$ per head a day was offered one week before and after the beginning of the mating season for flushing ewes and also during the last two to four weeks of pregnancy and through the first four weeks of lactation. Sheep were allowed to drink fresh tap water twice or thrice daily. Animals were sheared twice a year in March and August.

\section{Statistical analysis}

Using Average Information REMLF90 (AIREMLF90) software to estimate variance components and genetic parameters by Random regression model with Legendre polynomials (Misztal et al 2016). "Orthopolynom" package in R software used to estimate Legendre polynomials in different times (R Core Team, 2015). The best model fit using TableCurve 2D v5.01 software (Quadratic function) to estimate mean of monthly weights, the linear and quadratic regression coefficients for each animal. Coefficients were used to estimate covariance matrices, including estimates of genetic parameters. Fixed model was performed to adjust the effect of fixed factors using $R$ program software. The fixed main effects on body weights assumed in this study were gender (male or female), type of birth (single or twin), season of birth (1=lambs born from January to April, 2=born from May to August and 3=born from September to December), year of birth (34 years from 1984 up to 2017) and age of dam (1=ewes with age from 1328 months, 2=29-38 months, 3=39-50 months, 4=51-69 months and 5=ewes with age more than 69 months of age). Mean separation test of Duncan was used to compare between means. The main model used to estimate fixed factors was as follows.

$$
Y_{i j k l m n}=\mu+G_{i}+T_{j}+S_{k}+Y_{l}+D_{m}+e_{i j k l m n}
$$

where,

$$
\begin{array}{ll}
Y_{i j k l m n} & \text { is the weight of the } n^{\text {th }} \text { lamb in the } i^{\text {th }} \\
\text { gender, } j^{\text {th }} \text { type of birth, } k^{\text {th }} \text { season of } \\
\text { birth, } I^{\text {th }} \text { year of birth and } m^{\text {th }} \text { age of } \\
\text { dam; } \\
\mu \quad \text { is the overall mean; } \\
G_{i} \quad \begin{array}{l}
\text { is the effect of the } i^{\text {th }} \text { gender, } i=1 \\
\text { (male) and } 2 \text { (female); }
\end{array}
\end{array}
$$

(single) and 2 (twin);

$S_{k} \quad$ is the effect of the $k^{\text {th }}$ season, $k=1,2$ and 3 ;

$Y_{1} \quad$ is the effect of the $I^{\text {th }}$ year, $l=1$ to 34 ;

$D_{m} \quad$ is the effect of the $m^{\text {th }}$ age of dam, $m=$ 1 to 5 ; and

$\mathrm{e}_{\mathrm{ijk} \mathrm{mnn}}$ is the effect of random residual associated with the individual, assumed to be independent and normally distributed with $\left(0, \sigma_{e}^{2}\right)$.

The fixed model was fitted for every trait due to some significant interactions.

The general Random regression model fitted Legendre polynomials of age at recording (in days) as independent variables for the analysis was:

where,

$$
Y=X b+Z_{1 a}+Z_{1 p}+Z_{2 e}+\varepsilon
$$

$Y$ the observation vector of weight of lamb;

b the vector of fixed effects including fixed regressions;

a the vector of animal additive genetic effects for random regression;

$p$ the vector of permanent environmental effects for random regression;

e the vector of residual effects for random regressions;

$X \quad$ the incidence matrix for fixed effects;

$Z_{1 a}$ the incidence matrix for animal additive genetic effects;

$Z_{1 p}$ the incidence matrix for permanent environmental effects;

$Z_{2 \mathrm{e}}$ the matrix of covariates for each observation; and

$\varepsilon \quad$ the vector of random residual effect for the overall regression model, assumed to be independent and normally distributed with $(0$, $\left(\sigma^{2}\right)$.

\section{RESULTS AND DISCUSSION}

\section{Descriptive statistics}

Least squares means and their standard errors (LSM $\pm S E)$, coefficients of determination $\left(R^{2}\right)$ and coefficients of variation (CV\%) for body weights $(\mathrm{kg})$ are presented in Table 1. The least squares mean were $3.11,13.11,24.34,32.36,35.15$ and $40.26 \mathrm{~kg}$ for males and 2.95, 12.90, 22.61, 28.53, 30.88 and $35.31 \mathrm{~kg}$ for females for Bwt, Wwt, 6wt, $10 \mathrm{wt}, 12 \mathrm{wt}$ and $16 \mathrm{wt}$, respectively. Coefficients of variation ranged between 11.5 to $22.3 \%$ and determination coefficients ranged between 51 to 81 . 
Table 1. Least Squares Means and their Stander Errors (LSM $\pm S E)$, Coefficients of Determination $\left(R^{2}\right)$ and Coefficients of Variation (CV\%) for body weights $(\mathrm{kg})$ of Barki lambs at different ages.

\begin{tabular}{|c|c|c|c|c|c|c|}
\hline \multirow{2}{*}{ Classification } & \multicolumn{6}{|c|}{ Body weights (kg) } \\
\hline & Bwt & Wwt & 6wt & $10 w t$ & $12 w t$ & $16 w t$ \\
\hline Overall mean & $3.08 \pm 0.01$ & $13.01 \pm 0.08$ & $23.32 \pm 0.12$ & $30.13 \pm 0.16$ & $32.43 \pm 0.17$ & $37.24 \pm 0.45$ \\
\hline \multicolumn{7}{|l|}{ Gender } \\
\hline Male & $3.11^{a} \pm 0.02$ & $13.11^{\mathrm{a}} \pm 0.11$ & $24.34^{\mathrm{a}} \pm 0.18$ & $32.36^{a} \pm 0.24$ & $35.15^{a} \pm 0.27$ & $40.26^{a} \pm 0.82$ \\
\hline Female & $2.95^{\mathrm{b}} \pm 0.01$ & $12.90^{\mathrm{b}} \pm 0.12$ & $22.61^{b} \pm 0.16$ & $28.53^{\mathrm{b}} \pm 0.19$ & $30.88^{\mathrm{b}} \pm 0.20$ & $35.31^{b} \pm 0.50$ \\
\hline \multicolumn{7}{|l|}{ Type of Birth } \\
\hline Single & $3.04^{a} \pm 0.01$ & $13.07^{\mathrm{a}} \pm 0.08$ & $23.45^{\mathrm{a}} \pm 0.12$ & $30.17^{\mathrm{a}} \pm 0.16$ & $32.63^{\mathrm{a}} \pm 0.17$ & $37.46^{\mathrm{a}} \pm 0.47$ \\
\hline Twin & $2.90^{b} \pm 0.03$ & $12.20^{\mathrm{b}} \pm 0.26$ & $23.02^{b} \pm 0.45$ & $29.60^{\mathrm{b}} \pm 0.61$ & $31.89^{\mathrm{b}} \pm 0.69$ & $37.21^{\mathrm{a}} \pm 1.50$ \\
\hline \multicolumn{7}{|l|}{ Season $^{a}$} \\
\hline 1 & $3.07^{\mathrm{a}} \pm 0.02$ & $12.54^{\mathrm{c}} \pm 0.12$ & $23.83^{\mathrm{a}} \pm 0.18$ & $29.50^{\mathrm{b}} \pm 0.22$ & $31.50^{c} \pm 0.24$ & $36.20^{c} \pm 0.75$ \\
\hline 2 & $2.95^{c} \pm 0.02$ & $13.85^{\mathrm{a}} \pm 0.17$ & $22.53^{\mathrm{b}} \pm 0.21$ & $29.83^{b} \pm 0.27$ & $32.88^{b} \pm 0.29$ & $37.15^{\mathrm{b}} \pm 0.83$ \\
\hline 3 & $3.03^{b} \pm 0.02$ & $13.06^{b} \pm 0.12$ & $23.49^{\mathrm{a}} \pm 0.22$ & $31.61^{\mathrm{a}} \pm 0.34$ & $34.41^{\mathrm{a}} \pm 0.37$ & $39.55^{\mathrm{a}} \pm 0.78$ \\
\hline Age of Dam $_{1}^{b}$ & $3.05^{c} \pm 0.03$ & $13.03^{\mathrm{bc}} \pm 0.18$ & $23.13^{\mathrm{a}} \pm 0.31$ & $29.57^{\mathrm{a}} \pm 0.40$ & $31.85^{\mathrm{a}} \pm 0.42$ & $37.33^{\mathrm{a}} \pm 1.34$ \\
\hline 2 & $3.08^{b c} \pm 0.03$ & $13.21^{\mathrm{ab}} \pm 0.19$ & $22.92^{\mathrm{a}} \pm 0.30$ & $29.69^{a} \pm 0.36$ & $32.08^{\mathrm{a}} \pm 0.40$ & $37.19^{\mathrm{a}} \pm 0.92$ \\
\hline 3 & $3.12^{\mathrm{b}} \pm 0.03$ & $13.41^{\mathrm{a}} \pm 0.19$ & $23.50^{\mathrm{a}} \pm 0.32$ & $29.91^{\mathrm{a}} \pm 0.40$ & $32.35^{\mathrm{a}} \pm 0.45$ & $36.74^{\mathrm{a}} \pm 1.11$ \\
\hline 4 & $3.12^{b} \pm 0.03$ & $12.73^{\mathrm{c}} \pm 0.19$ & $23.15^{\mathrm{a}} \pm 0.31$ & $29.48^{\mathrm{a}} \pm 0.38$ & $31.94^{\mathrm{a}} \pm 0.40$ & $36.93^{\mathrm{a}} \pm 1.06$ \\
\hline 5 & $3.18^{\mathrm{a}} \pm 0.03$ & $12.80^{c} \pm 0.20$ & $22.98^{\mathrm{a}} \pm 0.32$ & $29.62^{\mathrm{a}} \pm 0.41$ & $32.43^{a} \pm 0.45$ & $37.81^{\mathrm{a}} \pm 1.11$ \\
\hline CV\% & 11.64 & 22.31 & 17.68 & 17.32 & 14.40 & 11.52 \\
\hline $\mathbf{R}^{2}$ & 0.73 & 0.56 & 0.64 & 0.51 & 0.70 & 0.81 \\
\hline
\end{tabular}

a: season: 1=lambs born at the period from January to April, 2=lambs born from May to August and 3=lambs born from September to December and b:(1=ewes with age from 13 to 28 months, $2=29$ to $38,3=39-50,4=51-69$ and $5=e$ wes with age more than 69 months). $P$ values $<0.05$ and the means with the same letter are not significantly different.

The overall average of body weights for Barki sheep at birth and yearling were intermediate between those reported before for the same breed whereas the values were $3.4,3.59,2.92,3.45$ and $3.46 \mathrm{~kg}$ at birth weight and 33.4, 31.92, 28.7, 32.7 and 23.82 at yearling weight, the values were lower than those reported before at weaning weight 18.2, 18.0, 14.1, 19.9 and 14.46 (Fahmy et al 1969, Mokhtar et al 1991, Ahmed et al 1992, Bedier et al 1995 and Salwa El-Wakil et al 2009), respectively. Lowing weaning weight attributed to the fact that lambs were weaned at 60 days in this flock.

\section{Non-genetic factors}

The results revealed that fixed effects (gender, type of birth, season, year and age of dam) and some of the first and second order interactions were generally significant on all studied traits $(P$ $<0.05)$. The effect of gender on body weights at different ages was highly significant $(P<0.001)$. Males weights were significantly higher than females from birth till the end of trajectory. Type of birth was significant $(P<0.05)$ and the lambs born single had higher weights than those born twins from birth till yearling and differences weren't significant after yearling. Season for birth was also significant $(P<0.05)$, lambs born from January to April had higher values at birth, lambs born from May to August had higher values at weaning and lambs born from September to December had higher values after weaning till the end of the trajectory. The effect of lambing season phenom could be due to the better environmental condition from November to May specially the availability of Egyptian clover. Lambing season from September to December was the best season for Barki sheep. Year of birth was the main significant effect on all body weight traits $((P<0.0001)$, this significant difference is attributed to the differences in subsequence managements and environmental condi- 

random regression model

tions. Age of dam at lambing had slight significant effect $(P<0.05)$ on all traits. However, Duncan comparisons showed that elder ewes gave highest birth weight for their lambs, ewes with moderate age (39-50 months) gave the highest weaning weight, while after weaning the differences were not significant. The results confirm what has been reported by other authors (Salwa El-Wakil et al 2009, El-Awady, 2011, Faid-Allah et al 2016, Hammoud \& Salem, 2017 and Naderi, 2018)

\section{Variance components}

Additive genetic variances $\left(\sigma^{2}{ }_{a}\right)$ for growth performance traits showed a tendency to increase with age till $13 w t(6.08 \pm 0.09)$ and subsequently decreased up to the end of the trajectory $(1.36 \pm 0.03)$ (Fig. 1B). This trend is similar to that obtained by Wang et al (2012) who used different models to estimate genetic parameters for growth traits of Qinghai fine-wool sheep in China and Naderi (2018) who used RRM for genetic evaluation and genetic trend of Makouei sheep growth. Whereas the trend reduced over time in Arabian sheep (Shokrollahi and Baneh, 2012) and Indian Malpura (Gowanea et al 2015). The highest estimate of $\sigma^{2}$ a was reported by Nemutandani et al (2015) when used RRM to estimate heritabilities and variance components for body weights from birth to six years of age in Merino sheep. ElAwady (2011) reported approximately the same values in the present study at Bwt, 4wt, 6wt and 12wt in Barki sheep. Figure 2 shows the additive genetic covariance $\left(\sigma^{2}\right.$ aco) estimates which were very low between the most of traits except between 10wt with 2wt, 6wt, 12wt, 13wt and 14wt and these high estimates may be explain the reason of increase of $h^{2}$ in $10 \mathrm{wt}$. Observed variation in the lamb's growth performance at these ages could have been caused by direct genetic effect.
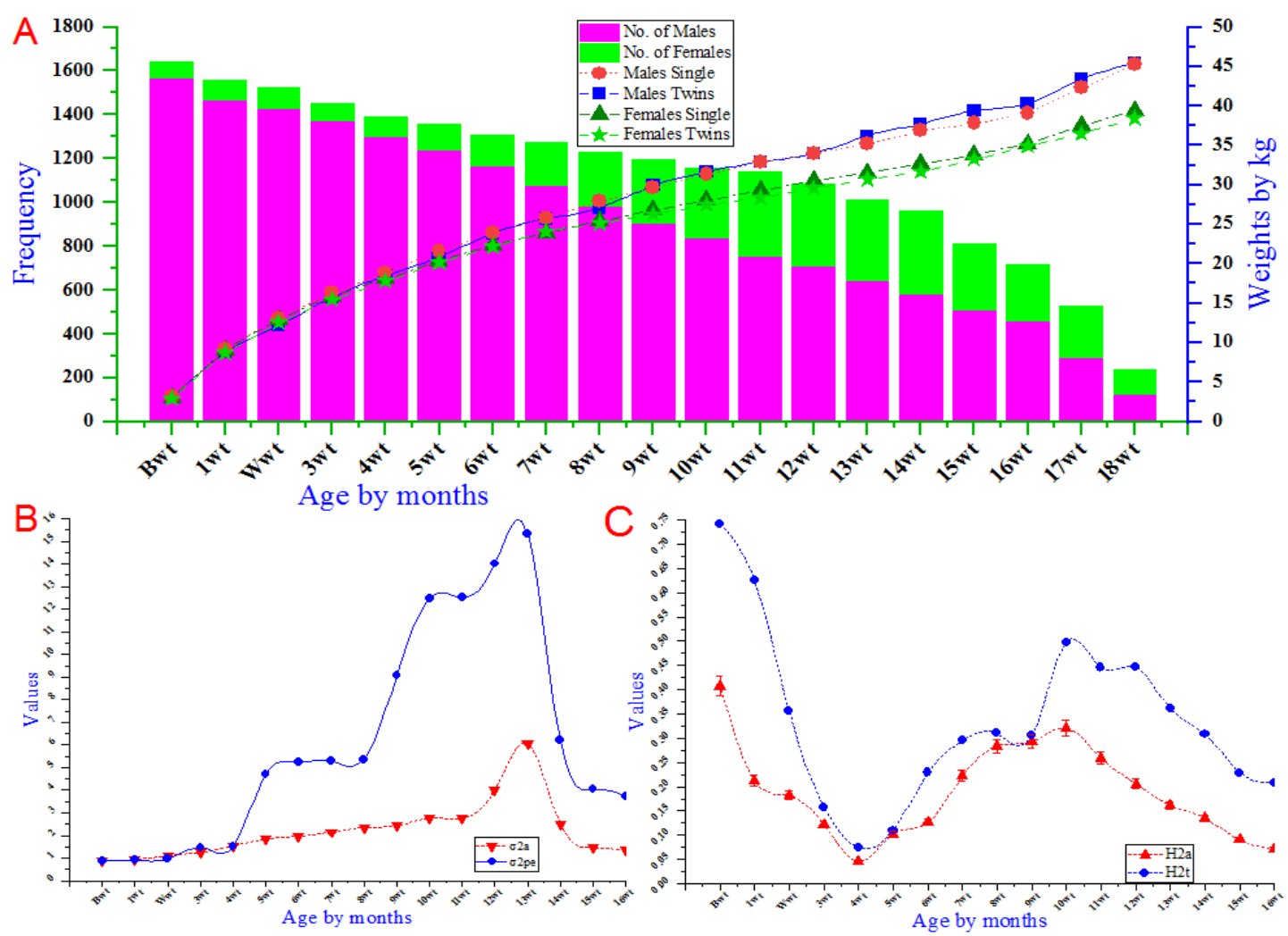

Fig. 1. A) Barki lambs growth curve for different gender with different type of birth which increase with lag of age and the number of male and female which decrease with lag of age in every body weight traits. B) Additive genetic $\left(\sigma_{a}^{2}\right)$ and permanent environment $\left(\sigma_{p e}^{2}\right)$ variances which increased by lag of age till 13wt and decreased after that to the end of trajectory. C) Additive genetic $\left(\mathrm{h}^{2}{ }_{\mathrm{a}}\right)$ and total $\left(\mathrm{h}_{\mathrm{t}}^{2}\right)$ heritabilities which have three stages:1) decrease from Bwt to $4 w t, 2)$ increase from $4 w t$ to $10 w t$ and 3) decrease again to the end of trajectory. 

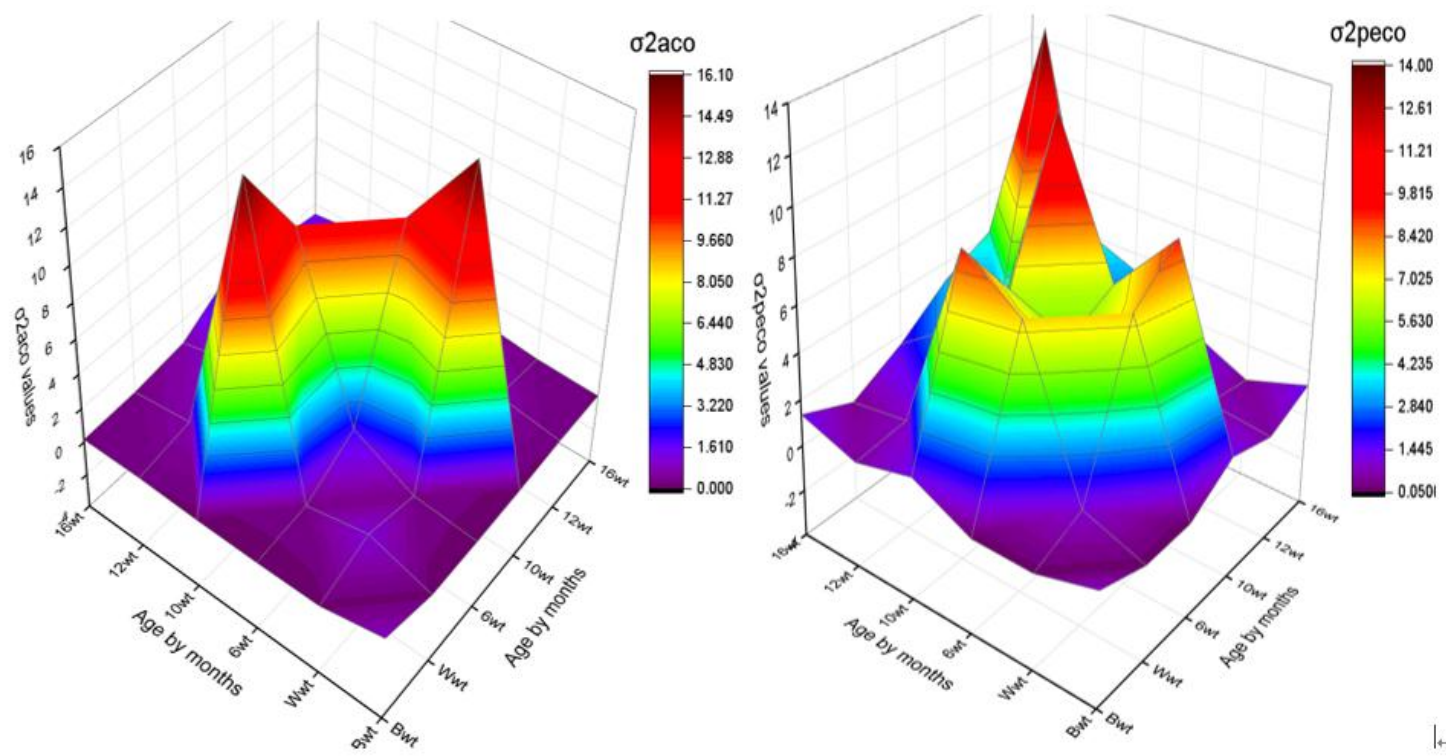

Fig. 2. Additive genetic $\left(\sigma^{2}{ }_{\text {aco }}\right)$ and permanent environment $\left(\sigma^{2}\right.$ peco $)$ covariances for the most important economic growth performance traits which increased till $10 \mathrm{wt}$ followed by decreased rate to the end of trajectory.

The trend of Permanent environment variances $\left(\sigma^{2}{ }_{p e}\right)$ took the same as $\sigma^{2}$, but $\sigma_{\text {pe }}^{2}$ had faster growth more than $\sigma^{2}$ a (Fig. 1B). The $\sigma^{2}$ pe values were estimated in the range from 0.88 to 15.32 with slightly increase till $4 \mathrm{wt}$ (1.52) followed by sharp increase till 13wt (15.32) and a general decrease to the end of trajectory afterward (3.72). The observed trend of $\sigma^{2}$ pe in the present study was similar to those reported in several breeds such as Moghani sheep in Iran (Najafi et al, 2011 and Zamani et al 2016), Sardi sheep in Morocco (Jannoune et al 2015) and Makouei sheep in Iran (Naderi, 2018). On the other hand, Fischer et al (2004) found general decreasing pattern for $\sigma^{2}$ pe from 100 to 500 days of age in Australian and New Zealand Poll Dorset sheep. Figure 2 shows the permanent environment covariance $\left(\sigma_{\text {peco }}^{2}\right)$ estimates which were low between the most studied traits, but higher than those of $\sigma^{2}$ aco, except between $6 \mathrm{wt}$ with $2 \mathrm{wt}$ and $10 \mathrm{wt}$, also between $11 \mathrm{wt}$ with $12 \mathrm{wt}$ and $13 \mathrm{wt}$ with $14 \mathrm{wt}$.

Although, phenotypic variance $\left(\sigma^{2} p\right)$ fluctuated between 2.27 and 22.56 for all body weight traits from Bwt to 16wt (Fig. 3D), for the most important economic attributes the trend was upward whereas the values were $2.27,6.15,15.61,17.89$ and 21.17 for Bwt, Wwt, 6wt, 10wt and 12wt, respectively. Similar estimates were reported for different populations such as Bharat Merino sheep in India (Gowane et al 2010), Qinghai fine-wool sheep in China (Wang et al 2012), Sardi sheep in Morocco
(Jannoune et al 2015), Makouei sheep in Iran (Naderi, 2018) and Barki sheep in Egypt (ElAwady, 2011).

The residual variance $\left(\sigma_{e}^{2}\right)$ estimated for all body weights took the same $\sigma^{2}$ p oscillated trend (Fig. 3D), while the trend increased with most important economic traits over age. The values were $0.06,1.28,1.97,2.12$ and 5.46 for Bwt, Wwt, 6wt, $10 \mathrm{wt}$ and $12 \mathrm{wt}$, respectively. Previous published papers reported that residual variance trend increased steadily with age advanced (Gowane et al 2010, El-Awady, 2011 and Wang et al 2012).

\section{Genetic parameters}

According to RRM, direct heritability $\left(\mathrm{h}^{2}{ }_{\mathrm{a}}\right)$ trend took three stages in the present study: in the beginning, $\mathrm{h}^{2}$ a values had a sharp decline from $0.41 \pm 0.02$ at Bwt to $0.05 \pm 0.00$ at $4 \mathrm{wt}$ followed by a gradual increase to $0.32 \pm 0.01$ at $10 \mathrm{wt}$ and eventually decreased again to $0.07 \pm 0.00$ at 16 wt (Fig. 1C). Low additive genetic values led to decline of $\mathrm{h}^{2}$ a values in the first four months. As the values of $\sigma^{2}{ }_{a}$ improved from the fifth month, the values of the $\mathrm{h}_{\mathrm{a}}{ }_{\mathrm{a}}$ increased, even though the increase wasn't high due to the faster increase of permanent environment values more than additive genetic values. The low values in preweaning period may be attributed to the low nutritional level whether from ewe milk or from nutrition supply and differences in management practices at the farm, creating a lee 

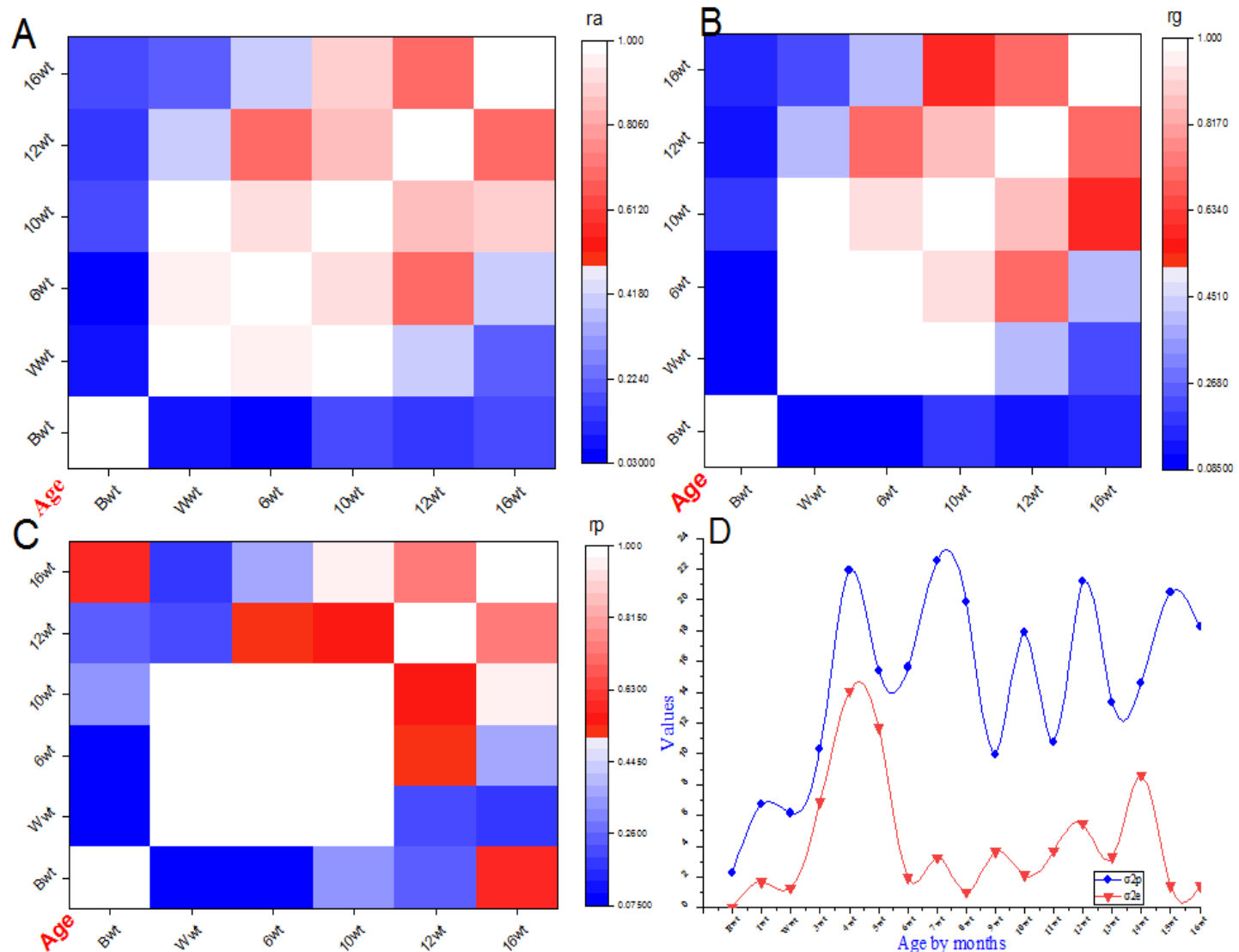

Fig. 3. A, B and C) Heat map for Additive $\left(r_{a}\right)$, genetic $\left(r_{g}\right)$ and phenotypic $\left(r_{p}\right)$ correlations which close to unity between Wwt, 6wt and 10wt. D) phenotypic $\left(\sigma_{p}^{2}\right)$ and residual $\left(\sigma^{2}\right)$ variances which were oscillated between months.

way for large environmental variations. Improved nutrition may be the main reason to increase the values gradually. Several researchers reported similar $\mathrm{h}^{2}$ a trend in different populations such as New Zealand and Australian Poll Dorset sheep (Fischer et al 2004), Sardi sheep in Morocco (Jannoune et al 2015) and Iranian Moghani sheep (Zamani et al 2016). On the other hand, some researchers established that $\mathrm{h}^{2}$ increased steadily with advancing age (Lewis and Brotherstone, 2002, Kariuki et al 2010 and Jannoune et al 2015). Hammoud and Salem (2017) estimated $h_{a}{ }_{a}$ of preweaning growth traits of Barki lambs and reported that values were $0.161-0.353$ and 0.100 0.171 for Bwt and Wwt while El-Awady (2011) established that $\mathrm{h}^{2}$ a for body weights showed $\mathrm{a}$ tendency to decrease over the time. Furthermore, Salwa El-Wakil et al (2009) estimated higher $h^{2}{ }_{a}$ value for Wwt (0.41) than Bwt (0.32) and 12wt (0.30).
Total heritability $\left(\mathrm{h}_{\mathrm{t}}^{2}\right)$ had a similar trend, but higher, to the $\mathrm{h}^{2}$. In the beginning, $\mathrm{h}_{\mathrm{t}}^{2}$ values had a sharp slipping from $0.74 \pm 0.01$ at Bwt to $0.08 \pm 0.02$ at $4 \mathrm{wt}$ followed by gradual growing to $0.50 \pm 0.01$ at $10 \mathrm{wt}$ and eventually decreased again to $0.21 \pm 0.01$ at 16wt (Fig. 1C). El-Awady (2011) used different animal models for estimating genetic parameters of Barki sheep and reported a lower estimate for $h^{2}{ }_{t}$ in all studied traits except Wwt. While Hammoud and Salem (2017) estimated the same values obtained in this study for Wwt but lower for Bwt. On the other hand, very low $\mathrm{h}^{2}$ were estimated in other populations (Ekiz et al 2004 and Gowane et al 2010). Generally, this wide range of $h^{2}$ estimates could be due to the differences in populations maintained at different locations, method of estimation, statistical models, initial matrices and selection criteria. The high heritability obtained during the time from $10 \mathrm{wt}$ to $13 \mathrm{wt}$ indicates a significant contribution of the $\sigma^{2}{ }_{a}$ to the phenotypic variation. 
Consequently, genetic improvement is possible for growth traits at this time by selection.

Additive $\left(r_{a}\right)$, genetic $\left(r_{g}\right)$ and phenotypic $\left(r_{p}\right)$ correlation coefficients estimated by RRM in Barki lambs from Bwt to $16 \mathrm{wt}$ had the same trend. Generally, the coefficients ranged from medium to unity, except for Bwt and 1wt, so selection for lambs' body weight at any age will improve weights at other ages. As shown in Figure $\mathbf{3 A}, \mathbf{B}$ and $\mathbf{C}$, the coefficients for $r_{a}$ between Bwt with all body weight traits ranged from low ( 0.03 with $6 w t)$ to moderate $(0.28$ with $13 w t)$, for $r_{g}$ ranged from low $(0.08$ with $6 w t)$ to moderate $(0.29$ with $13 w t)$ and from low (0.015 with $5 w t)$ to high (0.60 with $16 w t)$ for $r_{p}$. The lowest $r_{g}$ between Bwt and 1wt with other body weights indicates that body weights in younger ages are different from those at older ages. Such a result is fact of that different weights are controlled by different genes and this must be noticed in designing animal breeding strategies (Fischer et al 2004 and Kariuki et al 2010). The same results were given by Jannoune et al (2015) for Sardi sheep and Naderi (2018) for Makouei sheep using RRM. On contrast, El-Awady (2011) reported high $r_{a} 0.83,0.89$ and 0.67 between Bwt with Wwt, 6wt and $12 w t$, respectively, for the same breed using different animal models. The slight to moderate $r_{p}$ between younger and older ages is a sign of the efficiency of Barki lambs is extremely related to the ability to endure the production conditions like produce under the harsh conditions. Coefficients of $r_{a}$, $r_{g}$ and $r_{p}$ were high, close to unity, between Wwt (60 days) with $6 \mathrm{wt}$ and $10 \mathrm{wt}$, while were moderate with 12wt and 16wt. El-Awady (2011) estimated high coefficients between Wwt with 6wt and $12 w t$. The coefficient ranged from moderate to high $(0.36$ to 0.98 ) between $6 w t$ and other body weights traits. The highest correlation coefficients were found between 10wt and other traits (0.56 to 0.98). An adjacent body weights had higher correlation estimates than nonadjacent ones. These results emphasis the results given in many populations such as Zaraibi goats in Egypt (Mekkawy, 2000) and Moghani sheep in Iran (Zamani et al 2016). Only negative phenotypic correlation coefficients were estimated for some Bwt and 1wt traits. Negative $r_{p}$ was reported before in Santa Inês breed in Brazil (Oliveira et al 2010). However, Ghafouri-Kesbi et al (2008) and Kariuki et al (2010) didn't estimate any negative correlations. Anyway, correlations coefficients among longitudinal data or repeated measures depends mainly on genetic properties of the population and analysis methods.

\section{CONCLUSION}

Under the conditions of this study, the methodology based on RRM with Legendre Polynomials can be recommended for genetic evaluation of body weights from birth to 480 days in Barki sheep. The highest direct and total heritability for body weight traits after birth was at ten months of age and the highest additive and genetic correlation was between body weight at the same age with other body weight traits. Therefore, weight at ten months of age is considered the best criterion to give highest selection response for traits related to growth performance in Barki sheep breed. Different functions must be evaluated with different orders of fit, both in the fixed as in random regression because the behavior of the trajectory may be different for each data set.

\section{ACKNOWLEDGEMENT}

The authors is grateful to Associate Prof. Wagdy Mekkawy, Animal Production Department, Faculty of Agriculture, Ain Shams University and Prof. Shogo Tsuruta, Georgia University, USA (blupf90@yahoogroups.com) for their help in analyzing data.

\section{REFERENCES}

Ahmed A.M., Galal E.S.E. and Younis A.A. 1992. Estimates of productive and reproductive performances of a commercial flock of Barki sheep. Egyp. J. Anim. Prod., 29(1), 109-122.

Bedier N.Z., Younis A.A., Mokhtar M.M. 1995. Performance of Barki lambs in a stud ram flock. Desert Institute Bulletin, Egypt, 46(1), 1-7.

Ekiz B., Ozcan M. and Yilmaz A. 2004. Estimates of genetic parameters for direct and maternal effects with six different models on birth and weaning weight of Turkish Merino lambs. Turk. J. Vet. Anim. Sci., 28, 383-389.

El-Awady H.G. 2011. Different Animal Models for Estimating Genetic Parameters of Barki Sheep in Egypt. J. American Sci., 7(9), 882-887.

Fahmy M.H., Galal S.E.E., Ghanem Y.S. and Khishin S.S. 1969. Genetic parameters of Barki sheep raised under semi-arid conditions. Anim. Prod., 11, 361-367.

Faid-Allah E., Ghoneim E. and Ibrahim A.H.M. 2016. Estimated variance components and 

random regression model

breeding values for pre-weaning growth criteria in Romney sheep. JITV 21(2), 73-82.

FAOSTAT Statistics Database, 2016. Food and Agric. Organization of the United Nations, www.Fao.org/Faostat/am/\#home.

Fischer,T.M., Van der Werf, J.H.J., Banks, R.G. and Ball, A.J. 2004. Description of lamb growth using random regression on field data. Livest. Prod. Sci. 89, 175-185.

Ghafouri-Kesbi F., Eskandarinasab, M.P. and Shahir, M.H. 2008. Estimation of direct and maternal effects on body weight in Mehraban sheep using random regression models. Arch. Tierzucht. 51, 235-246

Gowane G R., Chopra A., Prince L.L.L., Paswan C. and Arora A.L. 2010. Estimates of (co)variance components and genetic parameters for body weights and first greasy fleece weight in Bharat Merino sheep. Anim., 4(3), 425-431.

Gowane G.R., Prince L.L.L., Lopes F.B., Paswan C. and Sharm R.C. 2015. Genetic and phenotypic parameter estimates of live weight and daily gain traits in Malpura sheep using Bayesian approach. Small Rumin. Res. 128, 10-18.

Hammoud M.H., and Salem M.M.I. 2017. Estimates of Variance Components and Heritabilities of Preweaning Growth Traits of Barki and Rahmani Lambs. Egyp. J. Anim. Prod., 54(3), 199-205.

Jannoune A., Boujenane I., Falaki M. and Derqaoui L. 2015. Genetic analysis of live weight of Sardi sheep using random regression and multi-trait animal models. Small Rumin. Res., 130, 1-7.

Kariuki C.M., Ilatsia, E.D., Wasike, C.B., Kosgey, I.S. and Kahi, A.K. 2010. Genetic evaluation of growth of Dorper sheep in semiarid Kenya using random regression models. Small Rumin. Res., 93, 126-134.

Kirkpatrick M., D. Lofsvold, and Bulmer M. 1990. Analysis of the inheritance, selection and evolution of growth trajectories. Genetics 124, 979-993.

Lewis R.M., and Brotherstone, S. 2002. A genetic evaluation of growth in sheep using random regression techniques. J. Anim. Sci. 74, 63-70.

Mansour H., Nordheim E.V. and Rutledge J.J. 1981. Estimators of Repeatability. Theor. Appl. Genet. 60, 151-156

Mekkawy W.A.I. 2000. Estimation of genetic parameters for growth performance of
Zaraibi Goats. M.Sc. Thesis. Anim. Prod. Dep., Fac. of Agric., Ain Shams Univ., Egypt, pp. 1-69.

Meyer K. 1998. Modeling "repeated' Records" Covariance Functions and Random Regression Models to Analyze Animal Breeding Data. Proc. $6^{\text {th }}$ World Congr. Genet. Appl. Livesst. Prod., Armidale, New South Wales Australia. 25, 517-520.

Meyer K. 2004. Scope for a random regression model in genetic evaluation of beef cattle for growth. Livest. Prod. Sci. 86, 69-83.

Misztal I., Tsuruta S., Lourenco, D., Masuda Y., Aguilar I., Legarra A. and Vitezica Z. 2016. Manual for BLUPF90 family of programs. Univ. of Georgia, Athens, USA. Last edit October 3, pp. 1-142.

Mokhtar M.M., Mansour H., Younis A.A. and ElGabbas H. 1991. Growth and mature size in fat-tailed sheep. Egyp. J. Anim Prod., 28(1), 39-46.

Mousa E., Mona A. Osman and EL-Saied U.M. 2006. Genetic Parameters for Body Weight of Egyptian Farafra Lambs with Random Regression Model. Egyp. J. Anim. Prod., 43(1), 5769.

Naderi Y. 2018. Genetic Evaluation and Genetic Trend of Growth of Makouei Sheep via Random Regression. J. Anim. Plant Sci. 28(2), 18.

Najafi, M.J., Lavvaf, A., Hemmati, B., Farahvash, T. and Abdollahpoor, R. 2011. Estimation of genetic parameters for growth traits in Moghani sheep using random regression. Res. Opin. Anim. Vet. Sci. 1, 677-685.

Nemutandani, K.R., Snyman M.A., Olivier W.J. and Visser C. 2015. Estimation of variance components and heritabilities for body weight from birth to six years of age in Merino sheep using random regression models. The World Congress on Genetics Applied to Livest. Prod., November.

Oliveira K.A.P., Lôbo, R.N.B. and Facó, O. 2010. Genetic evaluation of partial growth trajectory of Santa Inês breed using random regression models. Rev. Bras. Zootec. 39, 1029-1036.

Peng-yu W., Zhaxi G., Quan-Qing Q., Mao D., Yan-jun Z., Rui-jun W., Wen-guang Z. and Jin-quan L. 2012. Comparison and Analysis of Genetic Parameters of Growth Traits of Qinghai Fine-Wool Sheep Estimated by Different Models. Scientia Agric. Sinica, 45(1), 22802287. 
R Core Team, 2015. R: A language and environment for statistical computing. R Foundation for Statistical Computing, Vienna, Austria. https://www.R-project.org/.

Salwa El-Wakil, I., Shemeis, A.R., Ahmed, A.M. and Abdallah, O.Y. 2008. Genetic and phenotypic relationships involving body weight, degree of maturity and measures of gain rate of Barki sheep without having recourse to fitting growth curves. J. Agric. Sci. Mansoura Univ., 33, 4835-4848.

Salwa El-Wakil, Manal El-Sayed, Ahmed A.M., Sadek R.R. and Nigm A.A. 2009. Genetic and Phenotypic Parameters of Birth, Weaning and Yearling Body Weights of Barki Sheep Raised in the North Western Coast of Egypt. Egyp. J. Anim. Prod., 46(1), 43-52.

Schaeffer L.R. 2004. Application of random regression models in animal breeding. Livest. Prod. Sci. 86, 35-45.
Schaeffer L.R. and Jamrozik J. 2008. Random regression models: a longitudinal perspective. J Anim. Breed Genet. 125, 145-146.

Shokrollahi B. and Baneh H. 2012. (Co) variance components and genetic parameters for growth traits in Arabi sheep using different animal model. Genet. and Mole. Res., 11, 305314.

Talebi M.A., Miraei-Ashtiani S.R., NejatiJavaremi A. and Moradi-Shahrbabak $M$. 2007. Phenotypic and genetic characteristics of growth and carcass traits of Lori Bakhtiari sheep. Biotechnol. Anim. Husbandry. 23, 357- 363.

Van der Werf, J. and Schaeffer L.R. 1997. Random Regression in Animal Breeding, course notes, CGIL Guelph, June 25-28, pp. 1-59.

Zamani P., Moradi M.R., Alipour D. and Ghafouri-Kesbi F. 2016. Combination of BSpline and Legendre functions in random regression models to fit growth curve of Moghani sheep. Small Rumin. Res., 145, 115-122. 
تقدير المعالم الوراثية لصفات النمو في أغنام البرقي المصرية بإستخدام نموذج الإنحدار العشوائي

شريف مثلك- حسين منصور - عادل محمود أبوالنجا- منى أحمد عثمان - أحمد راضي البتاجيمنال السبد

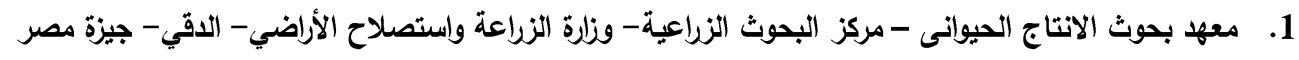

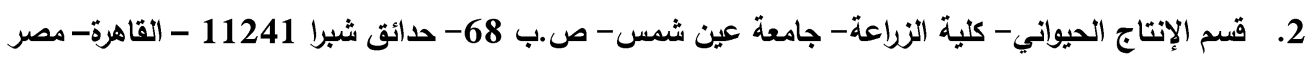

"Corresponding author: melakshaa@yahoo.com

0.88 إلى 15.33 لاوزان الجسم عند الميلاد وثلاثة

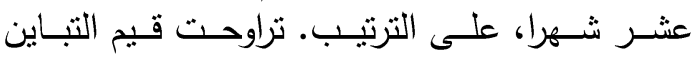
المشترك للتأثير الوراثى التجمعى والتأثير البيئى الدائم

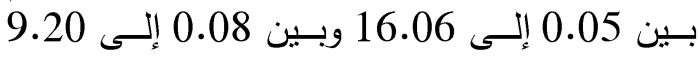

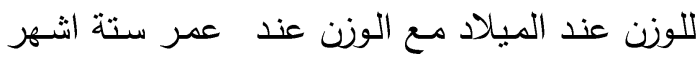

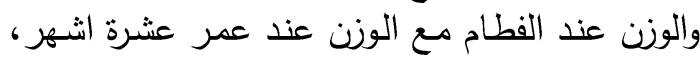
على الترتيب.

تراوحت قيم المكافئات الوراثية المباثرة والإجمالية

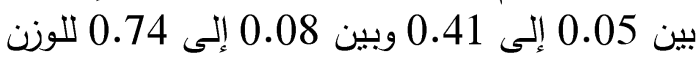

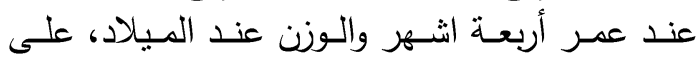

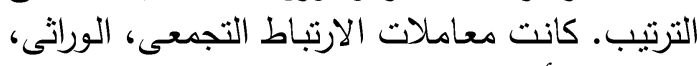

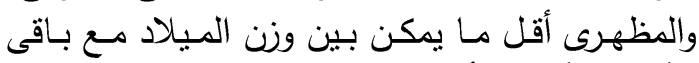

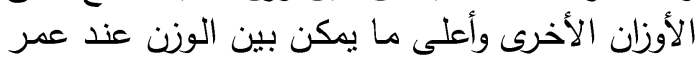

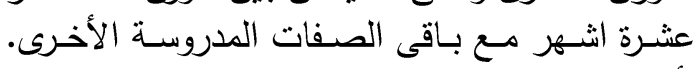

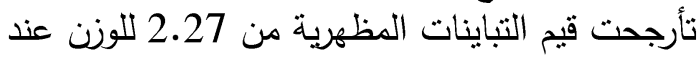

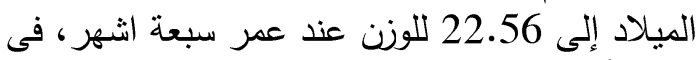

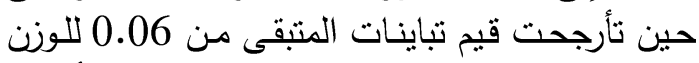

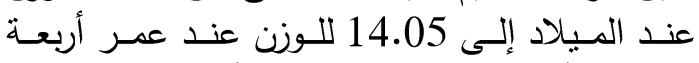

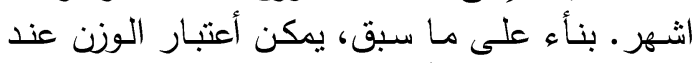

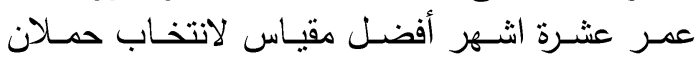
البرقى المصرية لإنتاج اللحم.

الكلمـات الدالـة: أغنـام البرقي، أداء النهـو، العواهـل

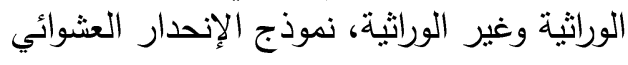

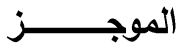

أجريــت هـــه الدراسـهـ لتقـدير مكونـات التبـاين

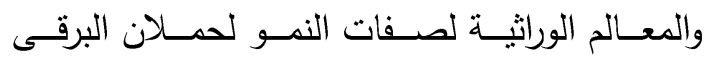

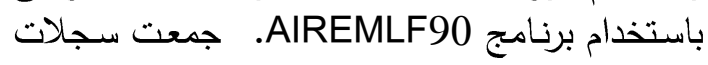

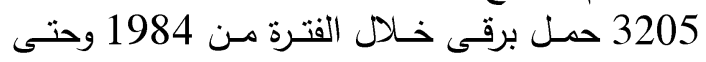

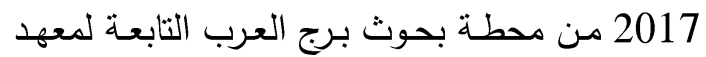

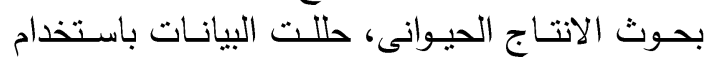

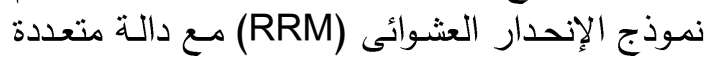

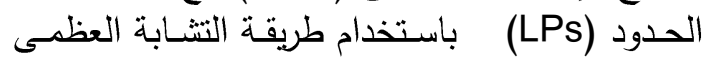
المحددة (REML) لتقدير مكونـات التباين والمعـالم

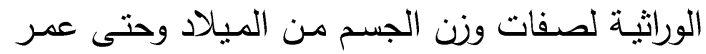
480

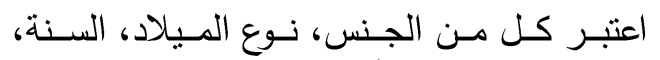

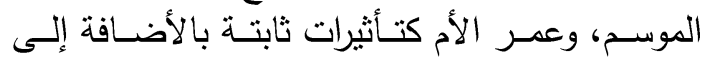

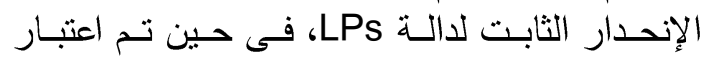

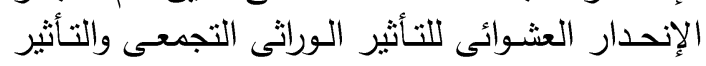

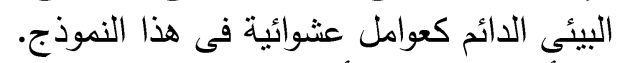

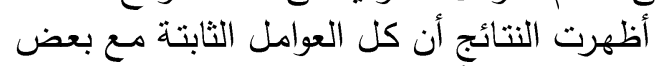

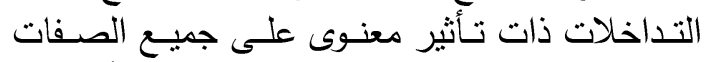

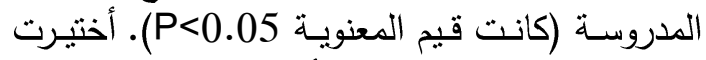

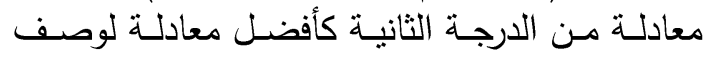

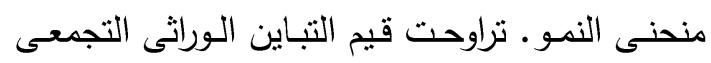
والتبـاين البيئسى الـدائم بـين 0.88 إلى 6.08 وبـين التين 